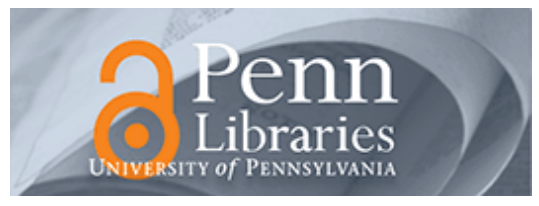

University of Pennsylvania ScholarlyCommons

January 2005

\title{
Science, Globalization, and Educational Governance: The Political Rationalities of the New Managerialism
}

Kathleen D. Hall

University of Pennsylvania, kdhall@gse.upenn.edu

Follow this and additional works at: https://repository.upenn.edu/gse_pubs

\section{Recommended Citation}

Hall, K. D. (2005). Science, Globalization, and Educational Governance: The Political Rationalities of the New Managerialism. Retrieved from https://repository.upenn.edu/gse_pubs/117

Postprint version. Published in Indiana Journal of Global Legal Studies, Volume 12, Issue 1, Winter 2005, pages 153-182. Publisher URL: http://muse.jhu.edu/journals/indiana_journal_of_global_legal_studies/

This paper is posted at ScholarlyCommons. https://repository.upenn.edu/gse_pubs/117

For more information, please contact repository@pobox.upenn.edu. 


\title{
Science, Globalization, and Educational Governance: The Political Rationalities of the New Managerialism
}

\begin{abstract}
The modern school has been a critical site for imagining possible publics and publicly-defining national purposes. Public education is presumed to provide a collective good to "a public"-"a public" of which the discourse about educational purposes conjures and addresses. Yet the imagined publics and purposes of education have varied considerably at different historic junctures. These variations have been shaped in part by the rise and fall in prominence of two contrasting political horizons and the quite distinctive roles they have envisioned for the state and the market. The first, articulated in classic form by Adam Smith in the Wealth of Nations, privileges the role of the free market, arguing that state efforts to promote the social good are ineffectual compared to unbridled market forces. The second stresses the state's central role in protecting its citizens from the vicissitudes of the market by insuring social security and increased well-being.

\section{Comments}

Postprint version. Published in Indiana Journal of Global Legal Studies, Volume 12, Issue 1, Winter 2005, pages 153-182. Publisher URL: http://muse.jhu.edu/journals/indiana_journal_of_global_legal_studies/
\end{abstract}




\title{
Science, Globalization, and Educational Governance: The Political Rationalities of the New Managerialism
}

\author{
Kathleen D. Hall*
}

\section{INTRODUCTION}

The modern school has been a critical site for imagining possible publics and publicly-defining national purposes. Public education is presumed to provide a collective good to "a public" - "a public" of which the discourse about educational purposes conjures and addresses. ${ }^{1}$ Yet the imagined publics and purposes of education have varied considerably at different historic junctures. These variations have been shaped in part by the rise and fall in prominence of two contrasting political horizons and the quite distinctive roles they have envisioned for the state and the market. The first, articulated in classic form by Adam Smith in the Wealth of Nations, ${ }^{2}$ privileges the role of the free market, arguing that state efforts to promote the social good are ineffectual compared to unbridled market forces. The second stresses the state's central role in protecting its citizens from the vicissitudes of the market by insuring social security and increased well-being.

Over the past century, assumptions about the state's responsibility for the social good have been intrinsic to various forms of governance across the globe. Political systems from socialism to social democracy to social liberalism-while differing in ideology and approach — have been founded upon the fundamental principle that issues of governance should be decided on the basis of benefits to "the social." As Nikolas Rose has argued, "Whatever their differences, in each case the term 'social' implied a kind of anti-individualism: the need to conceive of human beings as citizens of a wider collectivity who did not merely confront one another as buyers and sellers on a competitive market." ${ }^{3}$ The social state, to a greater or lesser extent, has been envisioned as a force for social progress, con-

\footnotetext{
* Kathleen D. Hall received her doctorate in sociocultural anthropology from the University of Chicago's Department of Anthropology. She is an Associate Professor in the Graduate School of Education and the Department of Anthropology at the University of Pennsylvania.

1. Michael Warner, Publics and Counterpublics 14 (2002).

2. See generally Adam Smith, An Inquiry into the Nature and Causes of the Wealth of Nations (Edwin Cannan ed., Modern Library 1994) (1776).

3. Nikolas Rose, Powers of Freedom: Reframing Political Thought 118 (1999).
} 
tributing to the gradual betterment of all citizens, while cushioning the hardships suffered by society's worst-off.

Many argue that the past thirty years have witnessed "the end of the social"the eclipsing of what for decades has been an inevitable horizon for political thought and action. ${ }^{4}$ The end of the social has corresponded to the return of the market and to a reworking of relations between government and capitalist markets. From New Zealand to Japan, states have implemented new styles of public service governance marked by a transformation in "ethos from one of bureaucracy to one of business, from one of planning to one of competition, from one dictated by the logics of the system to one dictated by the logics of the market and the

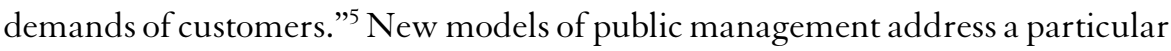
configuration of "the public," one inscribed within a utilitarian notion of the public sector's relationship to citizen-consumers. ${ }^{6}$ The business ethos of customer service has repositioned the public sector as product provider, and has shifted management's focus to serving its citizen-customers by providing quality services. ${ }^{7}$ The production and measurement of quality have become a central focus for governance systems, and public sector workers are held accountable for standards of performance and for producing results at less cost to the consumer (taxpayer). ${ }^{8}$ New public management discourse addresses "a public" depicted as customers who relate to their government on the basis of an economic, rather than

4. Jean Baudrillard, In the Shadow of the Silent Majorities or, The End of the Social and Other Essays (Paul Foss et al. trans., 1983) (discussing the difficulty in specifically defining "the social" and how that reflects on a political system which is premised on social representation).

5. Rose, supra note 3, at 150. For additional accounts of new public management, see Donald F. Kettr, The Global Public Management Revolution: A Report on the Transformation of Governance (2000) (surveying the global public management revolution and charting the major strategies in developed and developing nations around the world). See also Michael Barzelay, The New Public Management: Improving Research and Policy Dialogue (2001) (analyzing new public management and suggesting three key beliefs on how to improve the field); New Public Management: The Transformation of Ideas and Practice (Tom Christensen \& Per Laegreid eds., 2001) (examining the transformations of new public management and challenging the globalization thesis that new public management is fast spreading); New Public Management: Current Trends and Future Prospects (Kate McLaughlin et al. eds., 2002) (representing "a critical evaluation of the nature and impact of new public management").

6. Rose, supra note 3, at 164-65.

7. See generally Christopher Hood, A New Public Management for All Seasons?, 69 Pub. Admin. 3 (1991).

8. See id. at $4-5$. 
a social, contract—-through the logic of consumption—getting value for their dollars. ${ }^{9}$

New public management's recent embrace of free-market principles does not reflect a return to laissez-faire liberalism; for the role of the "neoliberal" state is not simply to "free" the market from social and political constraints, but rather to "enable" the market to work more effectively. The political imagery of the "social state" has been usurped by the notion of the "enabling state." ${ }^{10}$ Instead of providing for the public's needs "from the cradle to the grave," the state's role in the era of "advanced liberalism" is to enable citizen-consumers to take responsibility for their own well-being. ${ }^{11}$ New public management challenges the universalizing logic of citizenship associated with the welfare state wherein a citizen by virtue of birth possesses "certain common political, social and economic rights or entitlements ... secured by the state, in return for each citizen fulfilling certain obligations of responsibility, prudence, self-reliance, and civic

9. See generally Accountability: Power, Ethnos \& the Technologies of Managing (Rolland Munro \& Jan Mouritsen eds., 1996) (analyzing the role of calculation in governance); Michael Power, The Audit Society: Rituals of Verification (1997) (exploring the rapid growth of auditing as a tool for diverse groups). See generally Michael Herzfield, The Social Production of Indifference: Exploring the Symbolic Roots of Western Bureaucracy (1992) (examining bureaucracy through an anthropological framework). See Audit Cultures: Anthropological Studies in Accountability, Ethics and the Academy (Marilyn Strathern ed., 2000) (focusing on accountability regimes in neoliberal approaches to governance). For examples of how the last decade witnessed a turn among anthropologists to the study of social policy more broadly, see ANthropology of Policy: Critical Perspectives on Governance and Power (Cris Shore \& Susan Wright eds., 1997); Policy as Practice: Toward a Comparative Sociocultural Analysis of Educational Policy (Margaret Sutton \& Bradley A.U. Levinson eds., 2001). For examples of how anthropologists and historians have also recently turned their attention to analyzing the modern state and civil society, see generally Fernando Coronil, The Magical State (1997); Civil Society and the Political Imagination in Africa (John L. Comaroff \& Jean Comaroff eds., 1999); Democracy and Ethnography: Constructing Identities in Multicultural Liberal States (Carol Greenhouse \& Roshanak Kheshti eds., 1998); Timothy Mitchell, Rule of Experts: Egypt, Technopolitics and Modernity (2002); Julia Paley, Marketing Democracy: Power and Social Movements in Post-Dictatorship Chile (2001); James C. Scott, Seeing Like a State: How Certain Schemes to Improve the Human Condition Have Failed (1998); James Ferguson \& Akhil Gupta, Spatializing States: Toward an Ethnography of Neoliberal Governmentality, 29 Ам. Етнnologist 981 (2002); Michel-Rolph Trouillot, The Anthropology of the State in the Age of Globalization: Close Encounters of the Deceptive Kind, 42 Current Anthropology, Feb. 2001, at 125.

10. See Rose, supra note 3, at 142.

11. See id. at 141-42. 
duty." ${ }^{2}$ The responsibility of the state in the new public management system is to insure the quality of services that will enable citizens through acts of consumption to secure a better life.

In this paper I examine the transformation of educational governance in the era of new public management and the rise of the "enabling state." My aim is not simply to critique recent developments, but rather to analyze how power is exercised in the field of education through a new political rationality of governance and corresponding technologies of management. What is evident in education management reforms across the globe is a new way of thinking about the object, regulatory mechanisms, and role of governance. New accountability measures are being devised and deployed in efforts to control the risk and uncertainty endemic to public education. These efforts are taking many different forms. Over the past decade, for example, $\mathrm{K}-12$ education reforms in the United States have increasingly focused on instituting curriculum standards and assessing the quality of teacher and student performance through the mechanism of standardized tests. ${ }^{13}$ Yet while a good deal of media and research attention has been devoted to analyzing implications of these standardization efforts, the transformative capacity of other related state and federal government interventions is less widely recognized or fully understood. I focus on one of these developments, namely the increasing authority of the evidence-based policy move-

12. Id. at 253-54. There is a vast literature and set of debates surrounding the recent history of the welfare state in western capitalist nations in response to globalization. See generally NeIL GILbert, Transformation of the Welfare State: The Silent Surrender of Public ResponsibilITY (2002) (exploring the direction and essential qualities of modern changes in regard to statesponsored social protection in advanced industrialized countries worldwide); Duane Swank, Global Capital, Political Institutions, and Policy Change in Developed Welfare States (2002); Evelyn Huber \& John D. Stephens, Development and Crisis of the Welfare State: Parties and Policies in Global Markets (2001) (describing the development of welfare states in advanced industrial democracies in the first three postwar decades and the crisis these welfare states have faced in the past 20 years); Welfare States in Transition: National Adaptations in Global Economies (Gosta Esping-Andersen ed., 1996) (examining the welfare state in a historical and comparative perspective and analyzing its recent evolution and likely trends in light of changes in economic policy, social structures, and political configurations); Paul Pierson, Dismantling the Welfare State?: Reagan, Thatcher, and the Politics of Retrenchment (1994) (examining the effects of retrenchment politics on the welfare state during the administrations of Ronald Reagan and Margaret Thatcher). See Michael Katz, The Price of Citizenship: Redefining the American Welfare State (2001), for an in-depth and insightful historical analysis of the redefining of the American welfare state.

13. See generally Raising Standards or Raising Barriers? Inequality and High Stakes Testing in Public Education (Gary Orfield \& Mindy Kornhaber eds., 2001). 
ment in U.S. education policy. The primary focus of my analysis will be the legal codification of a new form of scientific managerialism in recent federal education policies and legislation, particularly in the No Child Left Behind Act of $2001 .^{14}$ The analysis will be presented in a series of steps. In part I, I provide a brief overview of the principles of the new public management paradigm. I then consider recent shifts in the role of science in U.S. federal education management reforms. I conclude with a discussion of some of the implications of this new configuration of educational expertise and governance for how education imagines its public and defines its public purpose.

\section{The Political Rationality of the New Public Management}

The global revolution in public sector management is founded upon a new political rationality, one that animates and legitimizes emergent systems of thought, strategies, and technologies for improving government performance. As Rose explains:

The critiques of welfare that have flourished over the past fifty years, in the post-war writings of neo-liberals such as Hayek, through the US critics of the New Deal and the War on Poverty and in contemporary 'post-social' political arguments from left and right, seek to rationalize government in new ways.... For example, the various tactics enacted by the British Conservative government under Margaret Thatcher in the 1980s were not realizations of any philosophy_whether it was Keith Joseph reading Adam Smith or one of his advisors reading Hayek. They were, rather, contingent lash-ups of thought and action, in which various problems of governing were resolved through drawing upon instruments and procedures that happened to be available, in which new ways of governing were invented in a rather ad hoc way, as practical attempts to think about and act upon specific

14. While my primary focus will be K-12 educational reform in the United States, this approach to scientific managerialism is being instituted across levels of educational governance. See Bonnie Urciuoli, The Language of Higher Education Assessment: Legislative Concerns in a Global Context, Ind. J. Global Legal Stud., Winter 2005, at 183, for an analysis of the legislation of assessment in higher education. 
problems in particular locales, and various other existing techniques and practices were merely dressed up in new clothes. ${ }^{15}$

Many of the principles associated with the new public management paradigm (NPM), were most widely applied first in New Zealand and Australia as well as in the United Kingdom during the Conservative Party's eighteen years in office, from 1979 to $1997 .{ }^{16}$ Despite a long history of Labour Party opposition to Thatcher's Conservative reform agenda, upon coming to office in 1997, Prime Minister Tony Blair's “New Labour” Party, following President Bill Clinton in the United States, embraced principles associated with the new public management as core components of the political "Third Way." ${ }^{17}$ In the United States, under Clinton and now George W. Bush, the NPM principles have become central to, in New Labour terms, "modernising government." As NPM principles have traveled from the discourse of Thatcherism to that of Clinton and Blair's "Third Way," their political significance has been radically redefined. No longer viewed as highly "ideological," entrepreneurial governance is now celebrated as "non-ideological," "nonpartisan," and simply, "pragmatic."

New public management reforms have been most aggressively championed in the Westminster nations-particularly Australia, the United Kingdom, and New Zealand—but have been on the agenda in states from Korea to Brazil, Portugal to Sweden. ${ }^{18}$ Reformers have often characterized the movement as an answer to the citizens' call "for responsive and efficient services, and significant pressures to reduce deficits and control public expenditure." ${ }^{19}$ Public service reforms have been shaped by a broad set of foundational principles that derive from a range of sources, in particular, the application of the new institutional economics

15. Rose, supra note 3 , at 27.

16. See generally Gernod Gruening, Origin and Theoretical Basis of New Public Management, 4 Int'L Pub. Mgmt. J. 1 (2001).

17. See Anthony Giddens, The Third Way and Its Critics 58 (2000). See generally Stephen Driver \& Luke Martell, Blair's Britain (2002) (describing the changes Tony Blair brought to the Labour Party); Colin Hay, The Political Economy of New Labour (1999) (emphasizing the New Labour Party's changing commitments on privatization and the public sector).

18. See, e.g., Christelle Auriacombe, Reflections on the New Public Management, 34 SAIPA, J. Pub. Admin. 2 (1999); Donald F. Kettl, The Global Revolution in Public Management: Driving Themes, Missing Links, 16 J. Pol'y Analysis \& Mgmt. 446 (1997).

19. Organisation for Economic Co-operation and Development, Issues and Developments in Public Management: Survey 1996-1997, at 85 (1997) [hereinafter OECD]. 
to public management. ${ }^{20}$ An Organisation for Economic Co-operation and Development (OECD) survey of several countries found the following principles to be widely shared:

1) a continuation of the trend towards devolving managerial authority to provide greater flexibility in achieving public policy goals, supported by improved resource management;

2) a closer focus on results ... by improving performance and enhancing accountability;

3) a stronger service quality orientation, which involves public consultation and leads to public services that are more relevant to needs and more responsive to demands;

4) a focus on adapting organisational structures, to improve service, performance, accountability and efficiency;

5) a heightened focus on the importance of an effective public sector workforce and leadership, to facilitate the stronger performance orientation and service-oriented public service culture;

6) regulatory reform as a tool to improve the capacity of governments to achieve policy objectives efficiently and cost-effectively; 7) a strengthening of steering functions at the centre to drive reforms strategically and promote policy coherence on cross-cutting issues, in the face of complex policy problems and a more devolved public sector environment. ${ }^{21}$

Business management inspired governance strategies champion the cause of making the public sector more citizen or consumer-centered, results-oriented, and market-based. Reform and renewal efforts are directed toward improving public sector performance (effectiveness and efficiency) through an emphasis on "results-based accountability." This approach to governance has become a

20. See Michael Barzelay, Origins of the New Public Management: An International View From Public Administration/Political Science, in New Public Management: Current Trends \& Future Prospects, supra note 5, at 15-33. A number of texts are noted for having "canonized" the new public management paradigm. See, e.g., Michael Barzelay, Breaking Through Bureaucracy (1992); David Osborne \& Ted Gaebler, Reinventing Government (1992) (playing an important role in influencing the Clinton Administration's policy); Hood, supra note 7 (coining the "new public management").

21. OECD, supra note 19, at 86-87 (emphasis omitted). 
taken-for-granted political good, as it has come to be articulated in policies and legislation ranging from the Clinton administration's 1993 National Partnership for Reinventing Government initiative and the corresponding Government Performance and Results Act of $1993,{ }^{22}$ to the New Labour's reform program, Modernising Government, introduced in 1999:23 to the Bush administration's education reform, the No Child Left Behind Act of 2001. ${ }^{24}$

While these public sector reform initiatives differ in detail and historical particularity, they share a rational scientific orientation to improving the effectiveness and efficiency of public sector performance. A key component of this orientation is the role of social science research, or "evidence," in policymaking. While efforts to base policymaking on sound social science research are hardly new ${ }^{25}$ more recently an emphasis on "evidence-based policy" has been enshrined in legislation, such as the No Child Left Behind Act in the United States, and in these words found in the 1999 U.K. White Paper entitled Modernising Government: "This Government expects more of policy makers. More new ideas, more willingness to question inherited ways of doing things, better use of evidence and research in policy making and better focus on policies that will deliver longterm goals." 26

David Blunkett, the British Secretary of State for Education and Employment, described his government's commitment to evidence-based policy in a speech that he gave at a meeting convened by the Economic and Social Research Council in 2000. As he explained,

It should be self-evident that decisions on Government policy ought to be informed by sound evidence. Social science research ought to be contributing a major part of that evidence base. It should be playing a key role in helping us to decide our overall

22. See John Kamensky, National Partnership for Reinventing Government: A Brief History (Jan. 1999), available at http://govinfo.library.unt.edu/npr/whoweare/history2.html (last visited Feb. 2, 2005).

23. Minister for the Cabinet Office, Modernising Government (Mar. 30, 1999), available at http:// www.archive.official-documents.co.uk/document/cm43/4310/4310.htm (last visited Feb. 2, 2005).

24. No Child Left Behind Act of 2001, 20 U.S.C. $§ 6301$ (2005).

25. See Carol H. Weiss, What Kind of Evidence in Evidence-Based Policy?, Remarks at the Third International, Inter-Disciplinary Evidence-Based Policies and Indicator Systems Conference 1-3 (July 2002), available at http://www.cemcentre.org/eb2003/Carol\%20Weiss\%20COLUMNS \%20WITHOUT\%20SHADING.doc (last visited Feb. 2, 2005).

26. Minister for the Cabinet Office, supra note 23, at ch. 2, para. 6. 
strategies.... This Government has given a clear commitment that we will be guided not by dogma but by an open-minded approach to understanding what works and why. This is central to our agenda for modernising government: using information and knowledge much more effectively and creatively at the heart of policy making and policy delivery. ${ }^{27}$

The turn to "evidence-based policy" in public sector governance is a global movement that is transforming public sector policy, practice, and research. ${ }^{28}$ As this movement has taken hold in the United States, arguments for the use of randomized field trials (RFTs) — particularly in the field of education as I will demonstrate below-have once again gained a central place on the federal policy stage. Randomized field trials have been used in public policy since the 1960s, most frequently perhaps in evaluations of welfare reform policies. The weaknesses of RFTs, both in the method itself and its political feasibility, have long been subject to debate. ${ }^{29}$ Yet, over the past decade, parallel to developments in the field of medicine, RFTs have come to be viewed as the "gold standard" of evaluation studies, particularly in efforts to assess the effectiveness of policy interventions in education, social welfare, and criminology. ${ }^{30}$ The dominance of this research design is due to its purported ability to determine causality, to measure the effect of a particular intervention on a specific result or outcome, and to

27. David Blunkett, Influence or Irrelevance: Can Social Science Improve Government?, Address at a meeting convened by the Economic and Social Research Council (Feb. 2, 2000), available at http://www.bera.ac.uk/ri/no71/ri7lblunkett.html.

28. See William Solesbury, Evidence-Based Policy: Whence It Came \& Where It Is Going 4 (2001).

29. See generally Robert A. Moffitt, The Role of Randomized Field Trials in Social Science Research: A Perspective from Evaluations of Reforms of Social Welfare Programs, 47 Ам. Bенаv. Sci. 506, 506-540 (2004); James J. Heckman, Randomization and Social Policy Evaluation, in Evaluating Welfare and Training Programs (Charles F. Manski \& Irwin Garfinkel eds., 1992); Gary Burtless, The Case for Randomized Field Trials in Economic and Policy Research, 9 J. Econ. Persp. 63, 63-84 (1995); James J. Heckman \& Jeffrey A. Smith, Assessing the Case for Social Experiments, 9 J. Econ. Persp. 85, 85-110 (1998).

30. For an example of the use of evaluation studies to assess the effectiveness of policy interventions in education, social welfare, and criminology, see the Campbell Collaboration's website at http://www.campbellcollaboration.org/Fralinks.html (last visited Feb. 1, 2005). 
generalize the findings or predict similar results across social contexts. ${ }^{31}$ It is, therefore, seen to be the ideal technology for a utilitarian form of governance focused on product and results, on being able to prove or predict what works. Randomized field trials provide a sense of certainty in an increasingly uncertain world. They allow for standardization at a historical moment when the coexistence of multiple "truths" or standpoint epistemologies are increasingly taken for granted. ${ }^{32}$ As Stefan Timmermans and Marc Berg in their study of evidencebased medicine aptly suggest:

Evidence-based medicine is part of a wider movement to generate uniformity and quality control by streamlining processes. In the broader historical context, standardization forms a powerful vestige of modernism lingering in an increasingly postmodern world. The notion that predictability, accountability, and objectivity will follow uniformity belongs to the Enlightenment master narratives promising progress through increased rationality and control. ${ }^{33}$

The quest for standardization is hardly new. As Max Weber argued long ago, rational bureaucratic authority is a central feature of modernity. ${ }^{34}$ Indeed, the present neoliberal turn to scientific standardization in the management of quality services harkens back to F.W. Taylor's use of the techniques of "scientific management" to increase the efficiency of labor production in the early years of the twentieth century. ${ }^{35}$

31. See Thomas D. Cook \& Monique R. Payne, Objecting to the Objections to Using Random Assignment in Educational Research, in Evidence Matters: Randomized Trials in Education Research 150-178 (Frederick Mosteller \& Robert Boruch eds., 2002). See generally Robert F. Boruch, Randomized Experiments for Planning and Evaluation: A Practical Guide (1997).

32. There is a rich literature focusing, broadly put, on the social construction of scientific facts and the basis of the authority placed in numbers that I cannot do justice to here, but which certainly informs this analysis. See generally Ian Hacking, Representing and Intervening (1983); Bruno Latour \& Steve Woolgar, Laboratory Life (Princeton Univ. Press 1986) (1979); Theodore M. Porter, Trust in Numbers: The Pursuit of Objectivity in Science and Public Life (1995).

33. Stefan Timmermans \& Marc Berg, The Gold Standard: The Challenge of EvidenceBased Medicine and Standardization in Health Care 8 (2003).

34. See Max Weber, Bureaucracy, in From Max Weber 232-235 (Hans Gerth \& C. Wright Mills eds., Galaxy Books 1958) (1946).

35. See Frederick Winslow Taylor, The Principles of Scientific Management (W.W. Norton \& Co. 1967) (1911). 
What I examine in the analysis that follows is how the evidence-based movement in public sector management involves not only the standardization of management, but also the regulation of expertise and standards of quality in social science research. In particular, the No Child Left Behind Act of 2001 marks a fundamental shift in the federal government's authority in the field of educational research. Throughout the legislation a single phrase is used repeatedly, one that explicitly requires that educational programs "use effective methods and instructional strategies that are based on scientifically based research." ${ }^{36}$ The Act also explicitly defines what will qualify as "scientifically-based research." In this way, the Act inscribes in law a specific set of standards for assessing quality in scientific research. ${ }^{37}$

Michael J. Feuer, Lisa Towne, and Richard J. Shavelson, researchers who have been central to the rethinking of education research standards, describe the significance of this "unprecedented federal legislation" with these words:

The No Child Left Behind Act of 2001 (HR1), which reauthorizes the Elementary and Secondary Education Act and provides billions of dollars in federal aid, contains 111 references to "scientificallybased research" - already granted acronym status inside the Beltway as SBR. In all areas of the law's broad reach, including the big ticket items - teacher quality, safe and drug-free schools, and Title 1 - states and localities will have to demonstrate that they plan to spend those funds on programs with a scientific track record. After years of envy for federal support received by their compatriots in medical, technological, agricultural, and physical research, educational researchers can now rejoice: Research is in. ${ }^{38}$

Yes, research is in. In this and related legislation, a new relationship between governance and "scientifically-based research" has been enshrined in law. These managerial efforts have been further elaborated within the U.S. Department of Education's Strategic Plan 2002-2007 in which "Goal 4" is to "[t]ransform [e]ducation into an [e]vidence-based [f]ield," and secondly, "[s]trengthen the qual-

36. No Child Left Behind Act of 2001, 20 U.S.C. $§ 6315$ (2005).

37. No Child Left Behind Act of 2001, 20 U.S.C. $§ 6368(6)$ (2005).

38. Michael J. Feuer et al., Scientific Culture and Educational Research, Educ. Res., Nov. 2002, at 4 (citations omitted). 
ity of educational research." ${ }^{39}$ In the sections that follow I take a closer look at these developments to consider the role of scientific authority in a "state enabling" approach to public service governance. How are the federal government's recent efforts to "strengthen the quality of education research" and "transform education into an evidence-based field" producing new technologies for shaping, guiding, and directing the conduct of government, researchers, school administrators, and teachers? How, in turn, does the production of education as an "evidence-based field" create the capacity for control through self-regulation?

\section{Rigorous Evidence: The Key to Progress in Education?}

Evaluation research has long been a critical tool that governments-of welfare and enabling states alike- - have used to analyze the effectiveness of state policies and funded programs. ${ }^{40}$ Yet, in recent years, scientific evidence, as I have argued, has become not simply a policy tool, but a technology of governance. As deployed in recent government policy and law, science has become a technique not only for assessing results, but also for shaping conduct to achieve certain ends.

During the past decade, the authority of "scientifically-based research" has been enshrined in the legal requirements for two types of federal education funding: direct support for the provision of educational services and grants for education research. While the purpose of these mandates remains consistent, definitions of "scientifically-based research" have varied considerably across different policies and legislation.

In January 1994, Congress passed the Goals 2000: Educate America Act (HR 1804). ${ }^{41}$ As is evident in the passage quoted below, the legislation blames inadequate funding for what it portrays as the absence of "a foundation of knowledge on which to design school improvements." It also calls upon the Office of Educational Research and Improvement (OERI) to develop a policy for dissem-

39. U.S. Dep't of Educ., Strategic Plan 2002-2007, at 5 (2002), available at http://www.ed.gov/ about/reports/strat/plan2002-07/plan.pdf.

40. The field of policy analysis is another highly contested terrain. There is a long history of debate concerning both the ideal relationship between research and policy making as well as the relative value of particular methods for assessing program effectiveness and quality. For recent discussions of alternative approaches to the framing of policy analysis and utilization of policy research, see Frank Fischer, Reframing Public Policy (2003); Deliberative Policy Analysis (Maarten Hajer \& Hendrik Wagenaar eds., 2003).

41. Goals 2000: Educate America Act, 20 U.S.C. $\$ 5801$ (2005). 
inating research materials, and establishes the National Education Research Policy and Priorities Board (NERPPB) to advise the government on educational priorities and approve standards for the conduct and evaluation of research:

A significant investment in attaining a deeper understanding of the processes of learning and schooling and developing new ideas holds the best hope of making a substantial difference to the lives of every student in the United States.... The failure of the Federal Government to adequately invest in educational research and development has denied the United States a sound foundation of knowledge on which to design school improvements.... The Office should develop a national dissemination policy that will advance the goal of placing a national treasure chest of research results, models, and materials at the disposal of the education decisionmakers of the United States.... A National Educational Research Policy and Priorities Board should be established to work collaboratively with the Assistant Secretary to forge a national consensus with respect to a long-term agenda for educational research, development, dissemination, and the activities of the Office. ${ }^{42}$

This legislation sets forth a vision for educational research and for the federal government's responsibility to provide leadership in the conduct and support of scientific inquiry into the educational process. ${ }^{43}$

The Congress declares it to be the policy of the United States to provide to every individual an equal opportunity to receive an education of high quality.... To achieve [that] goal ... requires the continued pursuit of knowledge about education through research, development, improvement activities, data collection, synthesis, technical assistance, and information dissemination. While the direction of American education remains primarily the responsibility of State and local governments, the Federal Government has a clear responsibility to provide leadership in the

42. Goals 2000: Educate America Act, 20 U.S.C. $§ 6002$ (2005).

43. See Goals 2000: Educate America Act, 20 U.S.C. $\$ 6011$ (2005). 
conduct and support of scientific inquiry into the educational process. ${ }^{44}$

By the late nineties, the role of social science research shifts in Congressional legislation from that of "pursuing knowledge about education" to providing evidence of program effectiveness. Scientifically-based research emerges as the vehicle for justifying federal program expenditures. In 1998, the Comprehensive School Reform Demonstration Program, ${ }^{45}$ otherwise known as the "Obey-Porter" legislation, appropriated $\$ 150$ million in federal funding to state education agencies for grants to help school districts adopt successful, research-based comprehensive school reform models. ${ }^{46} \mathrm{With}$ this action, Congress links educational funding to results as "proven" by scientifically-based research. Experimental-controlled comparisons are identified as the legitimate source of this required knowledge. ${ }^{47}$

The emphasis on the role of "scientifically-based research" in establishing the quality of programs was maintained in the 1998 Reading Excellence Act $(\mathrm{REA})^{48}$ which explicitly required that its funds be allocated exclusively to programs shown to be effective by "scientifically-based reading research." 49 The definition of scientifically-based research appearing in this legislation was crafted over months of negotiation and debate and with input from a large number of university-based researchers, "primarily with backgrounds in cognitive psychology." ${ }^{50}$ Requiring studies that "draw on observation or experiment" and "test the stated hypotheses," the act concludes that scientifically-based research:

(A) means the application of rigorous, systematic, and objective procedures to obtain valid knowledge relevant to reading development, reading instruction, and reading difficulties; and

(B) shall include research that-

44. Goals 2000: Educate America Act, H.R. 1804, 103rd Cong. § 912 (1994).

45. Comprehensive School Reform Demonstration Program, Pub. L. No. 105-78, 111 Stat. 1496 (1997).

46. See Robert E. Slavin, Evidence-Based Education Policies: Transforming Educational Practice and Research, Educ. Res., Oct. 2002, at 15.

47. See id.

48. Reading Excellence Act, 20 U.S.C. $\$ 6661$ (2005) (This act was substantially revised by the No Child Left Behind Act.).

49. See Reading Excellence Act, 20 U.S.C. § 6661 (2005).

50. Margaret Eisenhart \& Lisa Towne, Contestation and Change in National Policy on "Scientifically Based" Education Research, Educ. Res., Oct. 2003, at 31-32. 
(i) employs systematic, empirical methods that draw on observation or experiment;

(ii) involves rigorous data analyses that are adequate to test the stated hypotheses and justify the general conclusions drawn;

(iii) relies on measurements or observational methods that provide valid data across evaluators and observers and across multiple measurements and observations; and

(iv) has been accepted by peer-reviewed journal or approved by a panel of independent experts through a comparably rigorous, objective, and scientific review. ${ }^{51}$

As Congress began proceedings over the reauthorization of the OERI, attention turned to determining what types of educational research should be supported by federal grants. ${ }^{52}$ Drafts of this legislation contain yet another set of criteria for defining "scientifically valid research." 53 In an early draft of H.R. 4875, introduced by Representative Mike Castle (R-DE) in the summer of 2000, two different standards were proposed for "scientifically valid qualitative methods" and "scientifically valid quantitative methods." 54

In the midst of Congress's work on the OERI reauthorization, Professor Kenji Hakuta, then-chair of the NERPPB, recognizing the significance of this legislation for the future of the field, "turned to the [National Research Council (NRC)] to inject the voice of researchers into policy initiatives of this kind." ${ }^{55}$ In the fall of 2000 the NRC convened a committee of educational researchers to "investigate what constitutes scientific research in education." ${ }^{156}$ This committee, the National Research Council's Committee on Scientific Principles for Education Research, released its report, Scientific Research in Education, in November 2001.

In setting out its stated aim in applying science to education, the report compares the study of education to the study of the physical world and describes the process of school improvement metaphorically as social engineering.

51. Reading Excellence Act, H.R. 4328, 105th Cong. § 2252 (1998).

52. See generally Eisenhart \& Towne, supra note 50.

53. See generally Scientifically Based Education Research, Statistics, Evaluation, and Information Act of 2000, H.R. 4875, 106th Cong. (2000).

54. Michael Feuer \& Lisa Towne, The Logic and Basic Principles of Scientific Based Research, available at http://www.ed.gov/nclb/methods/whatworks/research/page_pg11.html.

55. Eisenhart \& Towne, supra note 50, at 32. My discussion here draws liberally from the analysis in this article written by two members of the NRC's committee.

56. Id. 
[T]o address challenges of, for example, low-performing schools, the "achievement gap," and language diversity, educators today require new knowledge to reengineer schools in effective ways.

To meet these new demands, rigorous, sustained, scientific research in education is needed. In today's rapidly changing economic and technological environment, schooling cannot be improved by relying on folk wisdom about how students learn and how schools should be organized. No one would think of designing a rocket to the moon or wiping out a widespread disease by relying on untested hunches; likewise, one cannot expect to improve education without research. ${ }^{57}$

Yet in defining the nature of scientific research, the report is quite inclusive: ethnographic research is granted equal scientific stature with randomized experimental designs. ${ }^{58}$ Each, along with other methods, meet what the committee identifies as the six guiding principles of scientific inquiry:

- Pose significant questions that can be investigated empirically.

- Link research to relevant theory.

- Use methods that permit direct investigation of the question.

- Provide a coherent and explicit chain of reasoning.

- Replicate and generalize across studies.

- Disclose research to encourage professional scrutiny and critique. ${ }^{59}$

After the release of this report, a hearing was called to gather expert testimony on issues concerning OERI reauthorization. ${ }^{60}$ Members of the NRC committee met with the Subcommittee on Education Reform of the U.S. House Education and Workforce Committee, chaired by Rep. Castle, where they presented relevant findings from their report. In their testimony they challenge the government's move toward mandating particular methods in federal legislation

57. Nat'l Res. Council, Scientific Research in Education 12 (Richard Shavelson \& Lisa Towne eds., 2002).

58. See id. at 81, 107-108, 123, 130.

59. Id. at 52.

60. Eisenhart \& Towne, supra note 50, at 33. 
that authorizes education research funding. Their argument, recorded in the Congressional Record, reads:

The NRC report makes clear that the objectivity and progress of scientific understanding in any field-not just education research-derives not from a given methodology or a given person. Rather, it comes from the community of researchers .... A federal education research agency should play a major role in spurring those improvements ... through mechanisms like ... developing high standards of quality in close collaboration with the field. ${ }^{61}$

In 2002, the bipartisan Education Sciences Reform Act (ESRA) ${ }^{62}$ replaced OERI with the new Institute of Educational Sciences (IES). This act legally enshrines yet another definition of scientifically valid research, one which "includes applied research, basic research, and field-initiated research in which the rationale, design, and interpretation are soundly developed in accordance with scientifically based research standards." ${ }^{63}$ The act also lays out specific "scientifically based research standards," but does not require the use of a particular method as was the case with REA's stipulation of studies that "test the stated hypothesis." ${ }^{64}$ These standards are fairly broad, with the exception that "only random assignment experiments" or other designs able to "eliminate competing explanations" be used in research that attempts to answer causal questions or make causal claims. ${ }^{65}$ As stated in the legislation, the term "scientifically based research standards" means research standards that "apply rigorous, systematic, and objective methodology to obtain reliable and valid knowledge relevant to education activities and programs," and "present findings and make claims that are appropriate to and supported by the methods that have been employed." ${ }_{66}$ This definition adds some flexibility, implying that standards cannot be prescribed a priori, but only as they are "appropriate to the research being con-

61. Lisa Towne, Testimony given to the United States House of Representatives Subcommittee on Education Reform (Feb. 28, 2002), available at http://edworkforce.house.gov/hearings/107th/ edr/oeri22802/towne.htm.

62. Education Sciences Reform Act, 20 U.S.C. $§ 9501$ (2002).

63. 20 U.S.C. $\$ 9501(20)$.

64. 20 U.S.C. $\S 9501(18)$.

65. 20 U.S.C. $\$ 9501(18)(B)(i v)$.

66. 20 U.S.C. $\S \S 9501(18)(A)(i)-(i i)$. 
ducted." ${ }^{67}$ The legislation lists a number of standards that might apply to a range of methods, while clarifying that causal claims can only be made on the basis of random assignment experiments:

- employing systematic, empirical methods that draw on observation or experiment;

- involving data analyses that are adequate to support the general findings;

- relying on measurements or observational methods that provide reliable data;

- making claims of causal relationships only in random assignment experiments or other designs (to the extent such designs substantially eliminate plausible competing explanations for the obtained results);

- ensuring that studies and methods are presented in sufficient detail and clarity to allow for replication or, at a minimum, to offer the opportunity to build systematically on the findings of the research;

- obtaining acceptance by a peer-reviewed journal or approval by a panel of independent experts through a comparably rigorous, objective, and scientific review; and

- using research designs and methods appropriate to the research question posed. ${ }^{68}$

The new Institute of Educational Sciences is charged with promoting "the use, development, and application of knowledge gained from scientifically valid research." ${ }^{69}$ As then-U.S. Secretary of Education Rod Paige expressed in a press statement announcing Bush's signing of the new Education Sciences Reform Act:

President Bush has grounded his agenda for education reform on doing what works based on scientific research. That means doing credible research on how learning and teaching can be improved; evaluating the effectiveness of educational approaches that incorporate research findings; providing statistical benchmarks for 
progress in education; and encouraging education decisions and policies that are based on evidence. We needed an invigorated research agency that is capable of carrying out a coordinated, focused agenda of high-quality research, statistics, and evaluation that is relevant to the educational challenges of the nation. The new law will help us meet these goals. ${ }^{70}$

In contrast to ESRA, the definition of "scientifically based research" enshrined a year earlier in the No Child Left Behind Act of 2001 maintains the prior preference for hypothesis testing and random assignment experiments:

The term "scientifically based research" (A) means research that involves the application of rigorous, systematic, and objective procedures to obtain reliable and valid knowledge relevant to education activities and programs; and (B) includes research that: employs systematic, empirical methods that draw on observation or experiment; involves rigorous data analyses that are adequate to test the stated hypotheses and justify the general conclusions drawn; relies on measurements or observational methods that provide reliable and valid data across evaluators and observers, across multiple measurements and observations, and across studies by the same or different investigators; is evaluated using experimental or quasi-experimental designs in which individuals, entities, programs, or activities are assigned to different conditions and with appropriate controls to evaluate the effects of the condition of interest, with a preference for random-assignment experiments, or other designs to the extent that those designs contain within-condition or across-condition controls; ensures that experimental studies are presented in sufficient detail and clarity to allow for replication or, at a minimum, offer the opportunity to build systematically on their findings; and has been accepted by a peer-reviewed journal or approved by a panel of independent

70. Secretary Rod Paige, Statement on the Signing of the Education Sciences Reform Act of 2002 (Nov. 6, 2002), available at http://www.ed.gov/news/pressreleases/2002/11/11062002a.html (last visited Feb. 2, 2005). 
experts through a comparably rigorous, objective, and scientific review. $^{71}$

The U.S. Department of Education published its Strategic Plan, 2002-2007 in March 2002. ${ }^{72}$ Similar to ESRA, no specific research method is prescribed. Yet the Plan's Strategic Goals explicitly link the government's emphasis on performance and results with "scientifically rigorous research on what works in education," or with randomized experimental field trials. ${ }^{73}$ As stated in Strategic Goal Four, education is to be transformed into an "evidence-based field." The government's rationale for this is explained in the following words:

Unlike medicine, agriculture, and industrial production, the field of education operates largely on the basis of ideology and professional consensus. As such, it is subject to fads and is incapable of the cumulative progress that follows from the application of the scientific method and from the systematic collection and use of objective information in policy making. We will change education to make it an evidence-based field. We will accomplish this goal by dramatically improving the quality and relevance of research funded or conducted by the Department, by providing policy makers, educators, parents, and other concerned citizens with ready access to syntheses of research and objective information that allow more informed and effective decisions, and by encouraging the use of this knowledge. ${ }^{74}$

The Plan further highlights two specific objectives: to "[r]aise the quality of research funded or conducted by the Department" and to "[i]ncrease the relevance of our research in order to meet the needs of our customers." ${ }^{75}$ Policy and practice decisions in education, like in medicine, are to be informed by rigorous evidence of effectiveness provided by well designed and executed randomized experimental field trials. While the Strategic Plan does not state what percent-

71. No Child Left Behind Act of 2001, H.R. 1, 107th Cong., § 1208(6) (2001).

72. U.S. Dep't of Educ., supra note 39, at 1.

73. Id. at $61-62$.

74. Id. at 59.

75. Id. at 59. 
age of its research grants will be allocated to funding randomized trials, it sets a performance target that 75 percent of funded projects addressing causal questions should employ randomized experimental designs. ${ }^{76}$

Calls to make education an evidence-based field draw from the arguments of certain groups of experts, while seemingly ignoring the views of others. ${ }^{77}$ The Coalition for Evidence-Based Policy, in their report "Bringing Evidence-Based Progress to Education: A Recommended Strategy for the U.S. Department of Education," strongly supports increased utilization in educational research of the "gold standard" of scientific research designs_-randomized, controlled field trials. ${ }^{78}$ The Coalition was established in 2001 by the Council for Excellence in Government. The Council describes itself as a "nonpartisan, nonprofit and national" organization, which works to improve the performance of government at all levels and to connect it to its citizens. ${ }^{79}$ In November 2002, the Coalition sponsored a forum, "Rigorous Evidence: The Key to Progress in Education? Lessons from Medicine, Welfare and Other Fields," which brought together high ranking government officials, including Paige and the then-new Director of IES, Grover "Russ" Whitehurst; leading policymakers; and academics to dis-

76. Id. at 61 .

77. These developments have sparked heated debates in the highly contested terrain of educational research. For analyses of these developments, see generally Philip Davies, What is EvidenceBased Education?, 47 Brit. J. of Educ. STud. 108 (1999); Feuer et al., supra note 38, at 4; Ann Oakley, Social Science and Evidence-Based Everything: The Case of Education, 54 Evuc. Rev. 277 (2002); Slavin, supra note 46, at 15 . For statements in support of the turn to randomized experimental designs, see generally Evidence Matters: Randomized Trials in Education Research, supra note 31; Thomas D. Cook, A Critical Appraisal of the Case Against Using Experiments to Assess School (or Community) Effects, Educ. Next, Fall 2001. For critical analyses of the turn to randomized trials, see Fredrick Erickson \& Kris Gutierrez, Culture, Rigor, and Science in Educational Research, Educ. Res., Nov. 2002, at 21; Joseph A. Maxwell, Causal Explanation, Qualitative Research, and Scientific Inquiry in Education, Educ. Res., Mar. 2004, at 3; Gary Natriello, Scientific Research in Education, 106 Tchrs. C. Rec. 329 (2004) (book review); Martyn Hammersley, Some Questions about Evidence-Based Practice in Education (Sept. 2001) (unpublished manuscript), available at http:// www.leeds.ac.uk/educol/documents/00001819.htm.

78. The Council for Excellence in Government: Coalition for Evidence-Based Policy, Bringing Evidence-Based Progress to Education: A Recommended Strategy for the U.S. Department of Education, A Report of the Coalition for Evidence-Based Policy (Nov. 2002), available at http://www. excelgov.org/displayContent.asp? Keyword=prppcHomePage (last visited Feb. 2, 2005).

79. The Council for Excellence in Government: Coalition for Evidence-Based Policy, About the Council, available at http://www.excelgov.org/displayContent.asp? keyword=abHomePage (last visited Oct. 16, 2004). 
cuss the issues and policy recommendations raised in its report. ${ }^{80}$ In the words of Jon Baron, Executive Director of the Coalition for Evidence-Based Policy, "in order to spark progress," the Coalition, recommends

a major shift in federal policy toward funding and effectively using randomized control trials in education. Now, randomized trials are considered the gold standard ... in a number of other fields, including medicine and welfare, for establishing which interventions work and which interventions don't work... [W] [Wat our Coalition proposes for your consideration is a major, sustained federal strategy to do two things: build a knowledge base of intervention, show effective and replicable randomized trials and provide strong incentives for the widespread use of these research proven interventions.... The statutory authority for these recommendations is based in large part on the scientifically based research concept in No Child Left Behind. That provision, which appears throughout No Child Left Behind, says that funded activity should be backed by, quote, "scientifically based research," which is defined in the law as including a preference for randomized trials. ${ }^{81}$

Rationales for the use of randomized trials draw parallels with the evidence-based movement in medicine. Educational interventions are also frequently compared to medical treatments. Valerie Reyna, a former senior research advisor at OERI, used this strategy in a presentation on scientifically-based evidence given at a government seminar in February 2002:

The bottom line here is these same rules about what works and how to make inferences about what works, they are exactly the

80. The Council for Excellence in Government: Coalition for Evidence-Based Policy, Policy Forum -November 2002, available at http://www.excelgov.org/displayContent.asp? NewsItemID $=5617 \&$ Keyword $=$ prppcEvidence (last visited Jan. 16, 2005).

81. Jon Baron, Briefing Report: Bringing Evidence-Driven Progress to Education, in The Council for Excellence in Government: Coalition for Evidence-Based Policy, Rigorous Evidence: The Key to Progress Education? Lessons from Medicine, Welfare, and Other Fields, (proceedings from a forum with Rod Paige held on Nov. 18, 2002), available at http://excelgov.org/usermedia/images/ uploads/PDFs/Final_Online_Version_-_November_18_Forum_Transcript.doc (last visited Feb. 2, 2005). 
same for educational practice as they would be for medical practice. Same rules, exactly the same logic, whether you are talking about a treatment for cancer or whether you're talking about an intervention to help children learn.... I have the word "brain surgery" up there. The reason I have the word "brain surgery" up there is that I think, you know, when we talk about medicine and things like brain surgery and cancer, it is very, very important to get it right. We all recognize that and most of us buy into that. You know, that you've got to have randomized clinical trials because we want to be able to benefit for these treatments for cancer. But when we teach students we really are engaging in a kind of brain surgery. We are [affecting] them one way or the other. Sometimes what we do helps, sometimes what we do, in fact, inadvertently, harms. We really don't know until we do a randomized clinical trial whether what we are doing is benefiting that student or not. We really don't know. It may be well intentioned, but that's not sufficient as we can see from the example from bleeding. So, it is brain surgery essentially and it deserves the same kind of respect for the nature of the consequences, in my opinion. ${ }^{82}$

In education, as in medicine, this concern with "what works" has led to the creation of organizations such as the Cochrane Collaboration in medicine ${ }^{83}$ and the Campbell Collaboration, which bring together researchers from the fields of criminology, social work, and education. Each organization is devoted to preparing, maintaining, and disseminating systematic reviews of scientific research to provide evidence to policymakers, practitioners, and public consumers. ${ }^{84}$

The U.S. Department of Education also recently incorporated systematic reviews into its overarching strategy for encouraging the use of scientific evidence-based standards in educational decisionmaking. In 2002, it awarded a

82. Valerie Reyna, What is Scientifically Based Evidence? What is Logic?, Remarks at the U.S. Department of Education's Working Group Conference on The Use of Scientifically Based Research in Education 4, 8 (Feb. 6, 2002), available at http://www.ed.gov/nclb/methods/whatworks/ research/transcript.doc (last visited Feb. 2, 2005) (emphasis added).

83. For more information about this organization, see The Cochrane Collaboration at http:// www.cochrane.org/index0.htm (Jan. 16, 2005).

84. See The Campbell Collaboration, at http://www.campbellcollaboration.org/ (last visited Feb. 2, 2005). 
five-year 18.5 million dollar contract to the Campbell Collaboration and the American Institute of Research to create the "What Works Clearinghouse" (WWC). The mission of WWC is "to provide educators, policymakers, researchers, and the public with a central and trusted source of scientific evidence of what works in education." ${ }^{85}$ As described on the WWC website:

The WWC aims to promote informed education decision making through a set of easily accessible databases and user-friendly reports that provide education consumers with ongoing, highquality reviews of the effectiveness of replicable educational interventions (programs, products, practices, and policies) that intend to improve student outcomes. To do this, the WWC developed standards for reviewing and synthesizing research and selected topics for review. The WWC is currently conducting systematic reviews of existing research, and producing WWC Reports that describe the findings of these reviews. A Technical Advisory Group (TAG) composed of leading experts in research design, program evaluation, and research synthesis works with the WWC to ensure the quality and integrity of its efforts. The TAG helps establish and validate the standards for reviewing research, informs the methodological aspects of the evidence reviews, suggests improvements to WWC Reports, and provides guidance to the WWC contractors. ${ }^{86}$

While it has adopted the Institute of Education Sciences definition of scientifically-based research, the WWC only reviews "causal research" or what it defines as scientifically-based research that proves "what works." ${ }^{87}$ The WWC has created a set of "evidence standards" that correspond to a research rating system:

The WWC Evidence Standards identify studies that provide the strongest evidence of effects: primarily well conducted random-

85. What Works Clearinghouse, at http://www.w-w-c.org/ (last visited Feb. 2, 2005).

86. What Works Clearinghouse, Overview, at http://www.w-w-c.org/whatwedo/overview.html (last visited Feb. 2, 2005).

87. What Works Clearinghouse, FAQS, at http://www.whatworks.ed.gov/faq/what_research_ count.html (last visited Feb. 2, 2005). 
ized controlled trials and regression discontinuity studies, and secondarily quasi-experimental studies of especially strong design.

- "Meets Evidence Standards"-randomized controlled trials (RCTs) that do not have problems with randomization, attrition, or disruption, and regression discontinuity designs that do not have problems with attrition or disruption.

- "Meets Evidence Standards with Reservations"—-strong quasiexperimental studies that have comparison groups and meet other WWC Evidence Standards, as well as randomized trials with randomization, attrition, or disruption problems and regression discontinuity designs with attrition or disruption problems.

- "Does Not Meet Evidence Standards"—studies that provide insufficient evidence of causal validity.

- "Does Not Pass Screen"—studies that are not relevant to the topic being reviewed. ${ }^{88}$

Systematic reviews focus on topics that reflect a wide range of "our nation's most pressing issues in education." ${ }^{99}$ Topics are prioritized according to their:

- potential to improve important student outcomes;

- applicability to a broad range of students or to particularly important subpopulations;

- policy relevance and perceived demand within the education community; and

- likely availability of scientific studies. ${ }^{90}$

WWC selects topics from among nominations it receives through emails from the public; meetings and presentations they sponsor; the What Works Network; suggestions from senior members of education associations, policymakers, and the U.S. Department of Education; and reviews of existing research. ${ }^{91}$ Cur-

88. What Works Clearinghouse, Standards, at http://www.w-w-c.org/reports/standards.html (last visited Feb. 2, 2005).

89. What Works Clearinghouse, Current Topics, at http://www.w-w-c.org/topics/current_ topics.html (last visited Feb. 2, 2005).

90. Id.

91. Id. 
rent topics include: Adult Literacy; Character Education; Delinquent, Disorderly, and Violent Behavior; Dropout Prevention; English Language Learning; Math Curriculum-Based Intervention; Peer-Assisted Learning; and Reading. ${ }^{92}$

The move to make reliable, rigorous, and relevant evidence about what works available is motivated in part by the way educational products have become commodified. Selling textbooks and other curricular toys and tools is big business and, in this marketplace, there is a perceived need to protect truth in advertising. Yet, systematic reviews are not only a form of consumer protection, but they have also become a central component of a larger movement to democratize expertise, or, more precisely, to get solid evidence into the hands of practitioners or consumers, who, it is believed, can then apply this knowledge to improve their instructional practice.

In a presentation available on the Internet, Whitehurst lays out his model for what he calls "evidence-based education." ${ }^{93}$ Evidence-based education brings together what he refers to as "professional wisdom" - practitioner knowledge_-and "empirical evidence" — scientific-based research and information. ${ }^{94}$ As he explains, evidence-based education is "the integration of professional wisdom with the best available empirical evidence in making decisions about how to deliver instruction." Professional wisdom, on the other hand, is "the judgment that individuals acquire through experience." Knowledge in the form of professional wisdom, he suggests, enables teachers to identify and incorporate local circumstances into their instruction. ${ }^{95}$ Empirical evidence, by contrast, is "scientifically based research from fields such as psychology, sociology, economics, and neuroscience, and especially from research in educational settings." It is also "empirical data on performance used to compare, evaluate, and monitor progress. ${ }^{" 96}$ Evidence-based education, then, involves "the integration of professional wisdom with the best available empirical evidence in making decisions about how to deliver instruction." 97

Yet in discussing research quality, Whitehurst warns that "[a]ll evidence is NOT created equal." ${ }^{98}$ Defining research in terms of method, he then distin-

92. Id.

93. Grover J. Whitehurst, Evidence-Based Education (Oct. 2002), available at http://www.ed.gov/ nclb/methods/whatworks/eb/edlite-index.html (last visited Feb. 2, 2005).

94. Id. at slide 6 (Evidence-Based Education).

95. Id. at slide 4 (What is professional wisdom?).

96. Id. at slide 5 (What is empirical evidence?).

97. $I d$. at slide 3 (What is EBE?).

98. Id. at slide 15 (Quality: Levels of evidence). 
guishes particular designs according to the "quality" of evidence they provide. From top to bottom he lists: Randomized Trials (true experiments); Comparison Groups (quasi-experiments); Pre-Post Comparisons; Correlational Studies; Case Studies; and, finally, Anecdotes. ${ }^{99}$

Why do we need both scientific evidence and professional wisdom, he asks? Because "without professional wisdom education cannot adapt to local circumstances or operate intelligently in the many areas in which research evidence is absent or incomplete." And "without empirical evidence education cannot resolve competing approaches, generate cumulative knowledge, or avoid fad, fancy, and personal bias." 100 Professional wisdom, in other words, is what allows teachers to improve their instructional practice by adapting to their local circumstances practices and programs that science has shown "to work."

To assist practitioners in deciding what evidence-proven programs to choose, various aids are becoming available. In December 2003, the Department of Education, the IES, and the National Center for Education Evaluation and Regional Assistance published Identifying and Implementing Educational Practices Supported by Rigorous Evidence: A User Friendly Guide, a document prepared by the Coalition for Evidence-Based Policy. ${ }^{101}$ In addition, specific websites are dedicated to informing educators about evidence-based programs. The North Central Regional Laboratory website called The Toolbelt: A Collection of DataDriven Decision Making Tools for Educators is one example of what are now numerous internet resources with the aim to help educators choose curricula and instructional strategies that scientific evidence suggests will work. ${ }^{102}$

\section{Conclusion: Is What Works All That Matters?}

The application of the new public management rationality in the field of education has prompted key shifts in how education addresses its public and constitutes its relationship to particular technologies and forms of expertise. The first involves a turn away from discussions of educational purposes and politics

99. Id.

100. $I d$. at slide 7 (Why are both needed?).

101. See generally The Council for Excellence in Government: Coalition for Evidence-Based Policy, Identifying and Implementing Educational Practices Supported by Rigorous Evidence: A User Friendly Guide (Dec. 2003), available at http://www.ed.gov/rschstat/research/pubs/rigorousevid/ index.html (providing links to each section of the publication) (last visited Feb. 2, 2005).

102. See Toolbelt, at http://www.ncrel.org/toolbelt/index.html (last visited Feb. 2, 2005). 
to a utilitarian emphasis on the quality of the educational product and on results, or evaluating "what works." The power of this utilitarian governance rationality has become increasingly linked to a legitimating discourse of scientific expertise and evidence. Scientific research is being called to contribute to a utilitarian effort to determine what works and to provide evidence of what works for research consumers - teachers, school administrators, policymakers, and parents. Scientific evidence, assumed to prove what works, is increasingly commodified and presented to the public on websites and in various publications, packaged as transparently reliable and politically neutral objective knowledge. Educational expertise, produced through the technology of scientific procedures, is circulated with the aim of enabling administrators to implement quality programs, teachers to alter their instructional practice, and parents to make more informed choices in relation to their child's education. Through this process and under the auspices of modernizing government, a new politics of knowledge is being deployed, one that is setting the parameters for how we think about the purposes of education and is silencing alternative forms of politics, educational visions, and expertise by challenging their usefulness, relevance, or scientific rigor.

Entrepreneurial governance aims to make government more open, transparent, consumer accountable, responsive, efficient, and cost effective. The systematic accumulation of usable knowledge of "what works," it is argued, will not only improve the performance of public sector services, such as education, but will contribute to making governance more democratic. Yet, contrary to being the democratizing force proponents suggest, this entrepreneurial shift in educational governance entails new configurations of power and expertise, or regimes of regulation and control. Debates about the nature of scientific research in education are defining the parameters of what counts as credible knowledge and what forms of knowledge are "relevant" and "useful" and, therefore, valuable and legitimate for inclusion in public debate about educational practice. This discourse is producing not only strategies for improving education, but the boundaries of what remains outside-unspoken, unspeakable, and unthinkable — within the terms of this debate. Fundamental questions about the purposes and politics of education and its relation to the common good cannot be easily formulated within a system orchestrated by the logic of calculation and of measuring outcomes and results. What matters is what works, it is said. Yet, is knowing what works all that matters?

The privileging of scientific expertise in the service of instrumental policymaking not only excludes particular issues from educational discourse, but also 
implicitly devalues the knowledge of local experts. In the professional field of education, this oversight has significant implications. It reinforces hierarchical relations of power between the producers of legitimate scientific knowledge (the methodologically well trained academic "experts") and those who "need" that knowledge to do what they do better. It de-legitimates knowledge produced in everyday practice- the knowledge of teachers, administrators, parents, as well as students themselves. Whitehurst's top-down expert model of "evidence-based education," for example, defines teachers' "professional wisdom" as that which will make expert knowledge work in particular local settings. ${ }^{103}$ It does not consider how teachers' professional knowledge and expertise might be incorporated into research on educational problems, inform the development of intervention strategies, or provide insight into what programs and practices work for them, under what circumstances, how, and why.

Yet, as Frank Fischer suggests, the role of social science in policy research has itself been limited historically by the contrasting purposes or functions of social science and policy-oriented research. ${ }^{104}$

[T] he influence of the social sciences is everywhere to be found in contemporary political discourse. But the role has been more to stimulate the political processes of policy deliberation than to provide answers or solutions to the problems facing modern societies. Although such deliberation is generally acknowledged to be important to effective policy development, this "enlightenment function" is not the analytic mission the policy-oriented sciences have set out for themselves. More ambitiously, they have sought to develop universal methods and practices designed to settle rather than stimulate debates. This traditional "neopositivist" understanding of the policy-analytic role not only rests on an epistemological misunderstanding of the relation of knowledge to politics; its continued reliance on a narrowly empirical mode of inquiry also hinders the field's ability to more directly approach what it

103. Whitehurst, supra note 93, at slide 4 (What is professional wisdom?).

104. These developments are related to the rise of policy research to a position of dominance in schools of education. For an insightful reading of tensions between disciplinary-based and policy research in education, see Shirley Brice Heath, Discipline and Disciplines in Educational Research: Elusive Goals?, in Issues in Educational Research: Problems \& Possibilities 203 (Ellen Condliffe Lagemann \& Lee S. Shulman eds., 1999). 
can —and should—do, namely, to improve the quality of policy argumentation in public deliberation. The field's outdated epistemological orientation impedes its ability to develop methods and approaches that facilitate this important enlightenment-oriented discursive function. ${ }^{105}$

The introduction of instrumental scientific rationality into public sector governance, as I have argued, raises a number of questions not easily addressed within the parameters of this paradigm. What are the political implications of a policy mission that focuses narrowly on providing solutions to, rather than stimulating ongoing deliberation about educational problems? What are the consequences of attempting to determine quality in education in relation to the logic of instrumental scientific rationality? What do we overlook when we approach educational provision as primarily an issue of management — of improving teacher quality or of achieving stronger accountability for results? A great deal of attention in the field of education and in popular discourse has been directed toward examining neoliberal policies such as vouchers or the privatization of local school management. Critics speak out against the transformation of education into a private good in the marketplace of academic credentials. Yet the emphasis on determining "what works" is, for the most part, accepted as inevitable, as a natural good. Largely overlooked is what Foucault describes as the expansion of the economic form into the social—in this case, the educational sphere—and the progressive eliding of any difference between the economic and the social.

Finally, what is yet to be determined, of course, is whether this new form of scientific managerialism itself will actually work. Will the enforcement of the managerial principles of accountability, efficiency, and program effectiveness lead to no child being left behind? More subtly, perhaps, what will be the lasting influences, if any, of the framing of educational purposes in terms of quantifiable accountability standards, educational processes in relation to interventions that can be isolated and measured, and education's public as citizen-consumers? It is left to the historians of the future to assess not only whether this form of governance worked, but how it worked, what it reflected about out society and culture, and, most significantly, the consequences of its workings.

105. Frank Fischer, Citizens, Experts, and the Environment: The Politics of Local KNOWLEDGE 70 (2000) (emphasis added and citations omitted). 